\title{
The importance of transnational corporations in research and development activities in the world
}

\author{
Piotr CheChelski ${ }^{1}$ \\ Institute of Agricultural Economics and Food Economy, National Research Institute
}

\begin{abstract}
The study attempts to assess the importance of transnational corporations (TNCs) regarding the research and development $(\mathrm{R} \& \mathrm{D})$ activities in the contemporary world economy. The scale of this phenomenon can be proved by the comparison of the R\&D expenditure of the largest corporations with the expenditure of the leading countries in this field and the analysis of the ranking of TNCs with the highest expenditure on research and development and ranking of the most innovative corporations. The study indicates the causes of changes in R\&D expenditure among the largest transnational corporations in the world and attributes of the most innovative ones.
\end{abstract}

Paper type: research article

Keywords: transnational corporations, countries, R\&D expenditure, reasons for changes in R\&D expenditure in TNCs, research and development activities

\section{Introduction}

The processes of innovation development in the world are realized to a large extent by transnational corporations (TNCs). The leading role of transnational corporations is the result of their economic power and the advantages they have (Zorska, 2007 , p. 30). This is also confirmed by the 2008 OECD opinion (Guinet \& De Backer, 2008) which states that regarding the research and development (R\&D) activity transnational corporations are key players shaping the size and location of R\&D in today's global economy. They are also the driving force behind the processed in-

\footnotetext{
1 pchechel@poczta.fm
} 
volved, such as, the internationalization of $\mathrm{R} \& \mathrm{D}$, international research and development cooperation, knowledge and technology transfer.

It has been assumed that except for the few highly-internationalized medium and large enterprises, transnational corporations are responsible for the level and directions of $\mathrm{R} \& \mathrm{D}$ worldwide. The dominant role of transnational corporations in $\mathrm{R} \& \mathrm{D}$ activity, which is reflected in the amount of expenditure of these companies on $\mathrm{R} \& \mathrm{D}$, is still maintained today, even though there have emerged trends which may indicate some change in their position over the years. The expenditure on $R \& D$ of governments and other institutions has been on the rise. It seems that this may be related to the change in the current innovation model, which involves the dissemination of R\&D activities in the context of innovative networks that increasingly involve smaller companies, but also with the growth of R\&D in developing countries (e.g. China, India).

The purpose of this article is to present the importance of transnational corporations in global research and development activity and to indicate causes and changes in R\&D spending among the world's largest TNCs and trends in this process. In the literature there are relatively few studies devoted to this subject. This is due both to the complexity of TNCs themselves, the ongoing transformations (mergers, organizational changes, etc.), and the reluctance of transnational corporations to disclose their strategic data.

\section{The largest global business entities and their expenditure on research and development}

In 2000, global R\&D spending amounted to 674 billion dollars, while in 2013 it reached 1,558 billion dollars, which is an increase of 131.2\% over this time (The 2015 $E U$ industrial ReD investment scoreboard. ReD ranking of the top 1000 non-EU companies, 2015). This demonstrates a rapid increase in R\&D spending on a global scale. These changes are largely caused by transnational corporations. According to the study by Odrobina (2015, p. 137), between 2003 and 2013, one thousand corporations allocated from $44 \%$ to $40 \%$ of global expenditure on R\&D. In addition, it should be noted that the efficiency of the money spent by corporations was higher and their share in the total number of patents issued for inventions was higher than their share in funds allocated for R\&D on a global scale (Poznańska \& Kraj, 2015, pp. 105-107).

According to the research conducted by Poznańska and Kraj (2015), in years 2007-2011 almost every fourth or every third patent for the invention belonged to 102 largest corporations in terms of expenditures on R\&D in the world.

The importance of TNCs in global research and development activity can also be proved by the list of 100 largest world business entities in 2010, of which 68 are transnational corporations, and only 32 are nation states. In this list (Table 1), Po- 

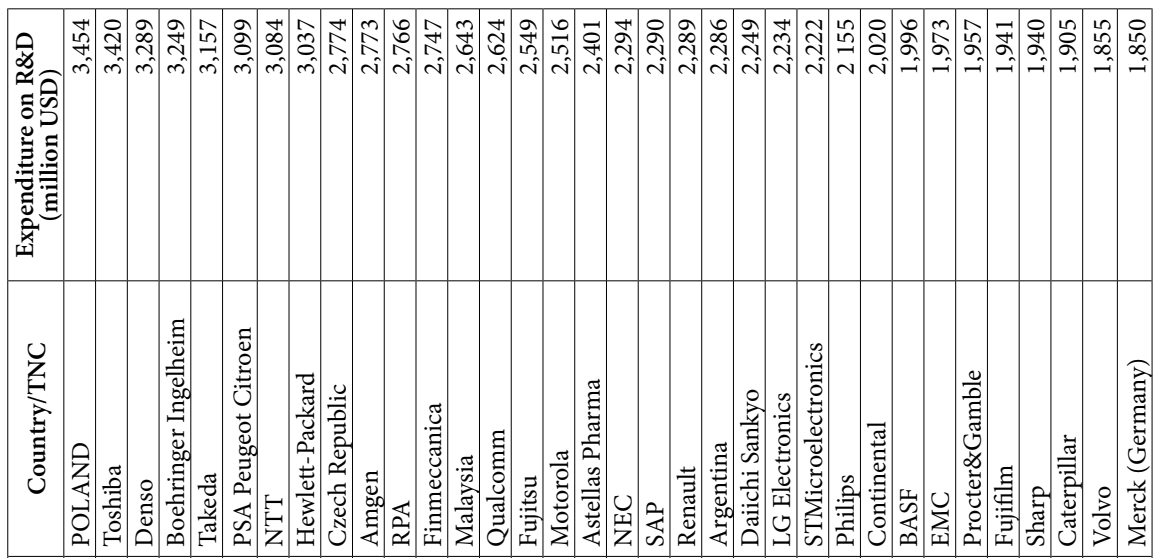

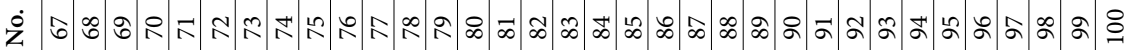

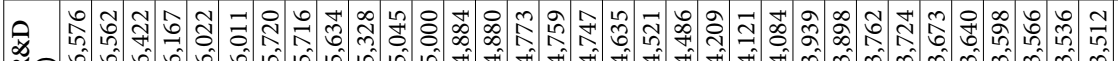

ㅍํㅇำ

害.

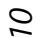

范家

৩

.

ఖ

范

:

t)

ฐึ)

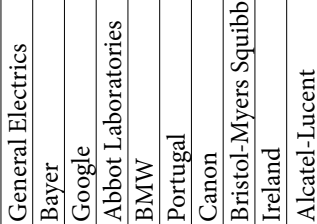

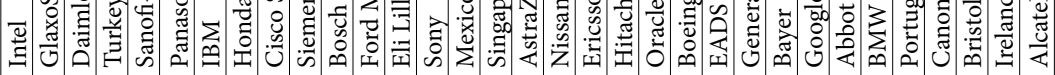

$\frac{1}{x}$

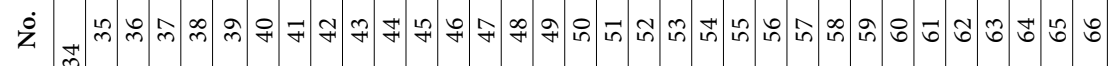

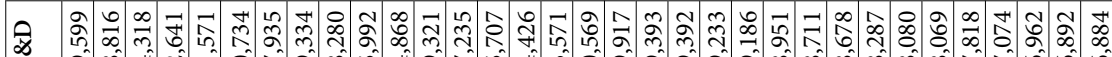

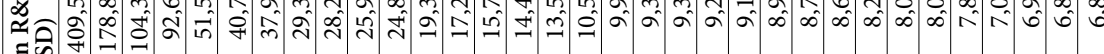

5

竞:

$\frac{2}{8}$

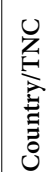

ఫ్త్ర

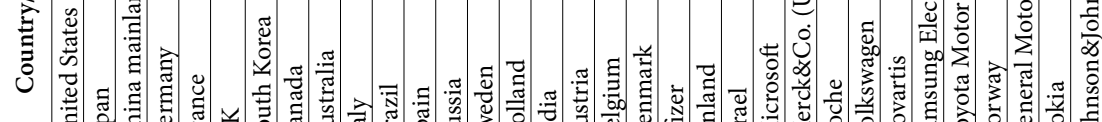

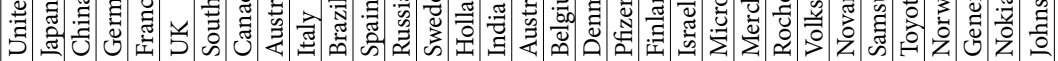

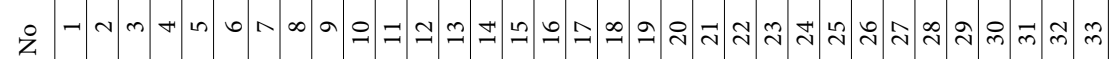

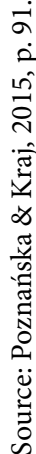


land was on the $67^{\text {th }}$ place while 27 countries and 39 transnational corporations were ahead of it. It should be noted that TNCs listed come from the USA, Japan, South Korea and highly developed European countries, i.e. countries ahead of Poland on the list.

Looking at the structure of the R\&D entities, one can hypothesize that the activity of TNCs to a large extent determines the directions and trends in R\&D in a global economy.

\section{Transnational corporations with the highest expenditure on research and development}

TNCs listed in Table 2 are active in four sectors: widely-understood healthcare (pharmaceutical, cosmetic, diagnostic and equipment for medical applications), represented by Novartis, Roche, Johnson \& Johnson, Pfizer, Merck US, SanofiAventis, GlaxoSmithKline; automotive: Volkswagen, Toyota Motor, General Motors, Ford Motor, Daimler, Honda Motor; electronic-electrical: Samsung Electronics, Siemens, Huawei, Robert Bosch, Panasonic and IT: Microsoft, Google, Apple, Intel, Cisco Systems, IBM.

These transnational corporations are companies operating mainly in technologically advanced industries with a broad production and research profile. They are also multidisciplinary with regards to their scientific and technical knowledge. With the exception of the South Korean Samsung and Chinese Huawei, the remaining TNCs come from the triad countries. Samsung, which in 2003 still was not on the list, in 2014 took the second place with a slight loss to leader Huawei, which entered the list in 2014 for the first time. Other TNCs coming from developing countries (e.g. India, China, Brazil) that are on lower places of the ranking list (2500) also moved up in the hierarchy.

Analysing the ranking list of the 20 TNCs with the highest expenditure on $\mathrm{R} \& \mathrm{D}$, one can conclude that over years 2003-2014 only 11 corporations remained on the list, which means that almost haft of the list changed. This demonstrates the enormous pressure among the largest corporations to acquire funding for research and development, and, at the same time, the conviction that only this type of activity will allow them to gain and maintain a global position.

The TNCs' leading position on the market is undoubtedly reflected by the scale and dynamics of their changes in expenditure on $\mathrm{R} \& \mathrm{D}$.

The analysis of the expenditure on R\&D of the 20 TNCs conducted in 20032014 shows two periods of development. The first is from 2003 to 2010, when their total expenditure increased from 82 billion euros to 142.7 billion euros, or by $74 \%$ (by more than $10 \%$ annually on average). It should be noted that at that time the world economy was experiencing the period of economic recovery in 2004-2007 and the economic crisis in 2008-2009. Therefore, the dynamics of changes of R\&D 


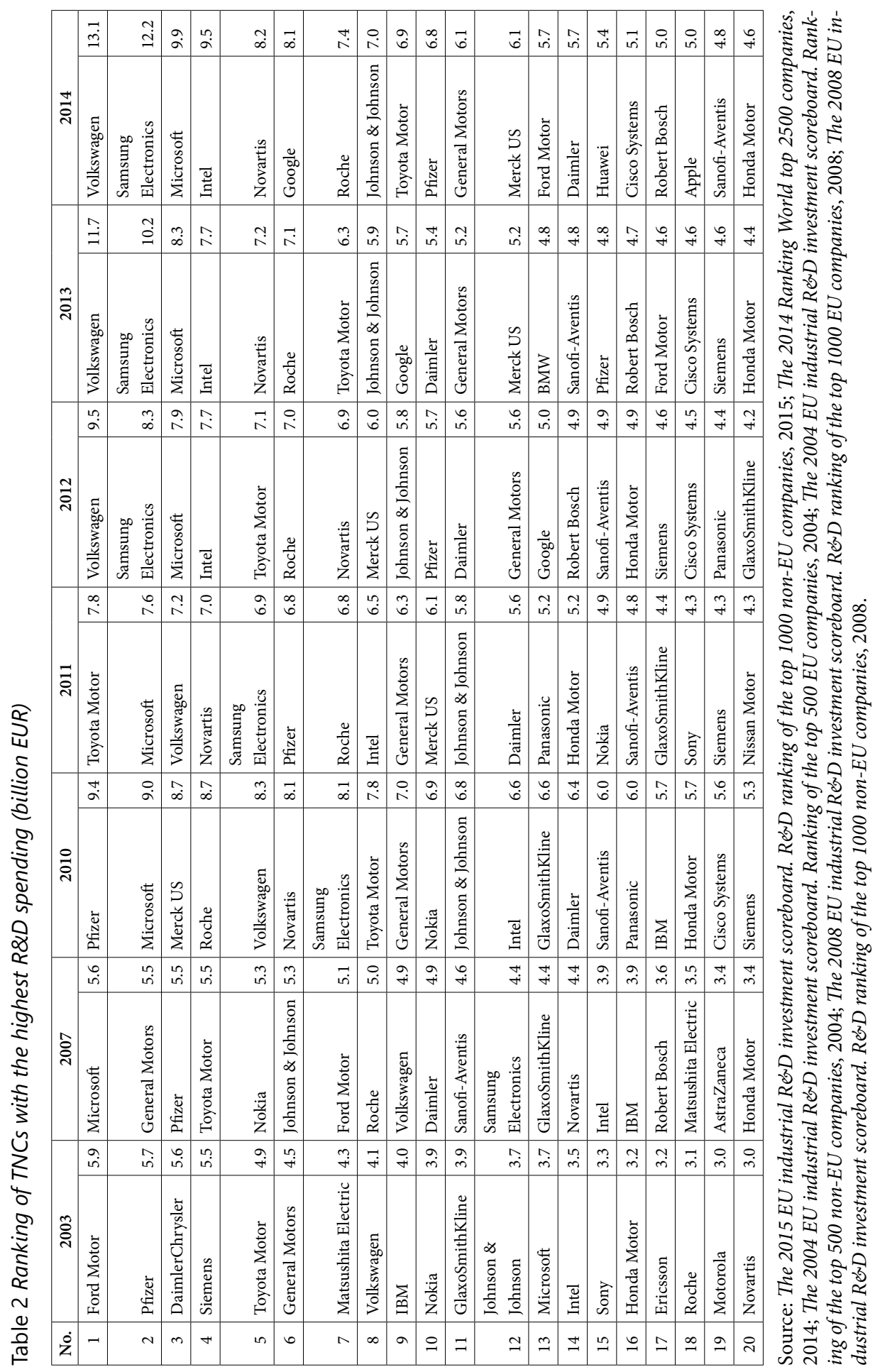


expenditures at that time should be considered high, as compared with other results of the world economy (e.g. GDP growth). This means that the largest transnational corporations allocated relatively large amounts on R\&D funding, despite the various conditions prevailing in the economic environment.

In subsequent years the total expenditure on $\mathrm{R} \& \mathrm{D}$ among the TNCs surveyed fell to 117.8 in 2011, 120.5 in 2012 and 123.2 billion in 2013. This may indicate that a few years of stagnation in the global economy regarding the amount of R\&D expenditure among the largest TNCs turned out to be more dangerous than previous economic fluctuations.

Only after four years, in 2014, did they return to the levels from 2010, that is, to 142.6 billion euros. On this basis it can be stated that the largest TNCs tend to spend more on R\&D during the times of economic prosperity (the so-called procyclicality of expenditure). ${ }^{2}$ The study of R\&D expenditure according to the industry sector (Table 3 ) shows that its structure changed significantly between 2010 and 2014 . The TNCs' share in the healthcare sector decreased by $-25.8 \%$, while the shares of other sectors increased.

Table 3 Changes in the industry sector for 20 TNCs with the highest R\&D expenditure in 2010 and 2014

\begin{tabular}{|c|c|c|c|c|c|c|}
\hline \multirow[b]{2}{*}{ No. } & \multirow[b]{2}{*}{ Industries } & \multicolumn{2}{|c|}{ R\&D expenditure in 2010} & \multicolumn{2}{|c|}{ R\&D expenditure in 2014} & \multirow{2}{*}{$\begin{array}{c}\text { Dynamics } \\
\text { of changes } \\
2014 / 2010 \text { in \% }\end{array}$} \\
\hline & & $\begin{array}{c}\text { billion } \\
\text { euros }\end{array}$ & $\%$ & $\begin{array}{c}\text { billion } \\
\text { euros }\end{array}$ & $\%$ & \\
\hline 1 & Healthcare & 54.3 & 38.0 & 40.3 & 28.3 & -25.8 \\
\hline 2 & ICT & 33.8 & 23.7 & 37.6 & 26.4 & 11.2 \\
\hline 3 & Automotive & 35.2 & 24.7 & 42.1 & 29.5 & 19.6 \\
\hline 4 & Electronic-electrical & 19.4 & 13.6 & 22.6 & 15.8 & 16.5 \\
\hline 5 & Overall & 142.7 & 100 & 142.6 & 100 & - \\
\hline
\end{tabular}

Source: own study based on Table 2 .

The decreased share of the healthcare was the result of GlaxoSmithKline dropping out of the list of companies and a significant reduction in R\&D expenditures of the largest companies in the industry between 2010 and 2014, i.e. Pfizer and Merck US cut their spending by 2.6 billion euros, Roche by 1.3 billion euros, etc. During this time, 5 corporations from different branches were subject to rotation, which also had some impact on the dynamics of changes in particular industries. It should also be noted that in the following years, TNCs allocated various amounts

2 Poznańska and Kraj (2015) observed such trends only in years 2000-2010, both in the analysis of the business sector of 56 countries, and the analysis of TNCs leading in terms of expenditure on R\&D. 
on R\&D depending on their current abilities (Table 4). For example, industry leaders in years 2010-2014 allocated the following amounts on R\&D: Volkswagen 49.8, Microsoft 42.7, Samsung 45.7 and Novartis 37.2 billion euros.

Ranking leaders, in search of competitive advantage, continuously increased their R\&D spending. For example, Volkswagen increased it by $219.5 \%$ over 11 years. This led to increasing differences in expenditure on R\&D. In 2003, the leader of the ranking, Ford Motor, allocated 5.8 billion euros, while the $20^{\text {th }}$ place in the list, Honda Motor, 3.4 billion euros. The difference amounted to 2.4 billion euros, or $70.6 \%$. In 2010 Pfizer spent 9.4 billion euros, and the last one on the list was Siemens with 5.3 billion spent, which means that the difference rose to 4.1 billion euros, or $77.4 \%$. On the other hand, the first on the list, Volkswagen, spent 13.1 billion euros in 2014, and Honda Motor, which was on the $20^{\text {th }}$ place on the list, spent 4.6 billion euros, so the difference rose to 8.5 billion euros, or $184.8 \%$. The result is a growing dominance of the largest TNCs over the remaining corporations and greater stabilization on the top positions in the ranking lists.

Table 4 Changes in R\&D expenditure in 2003 and 2014

\begin{tabular}{|r|l|c|c|c|c|}
\hline \multirow{2}{*}{ No. } & & $\mathbf{2 0 0 3}$ & $\mathbf{2 0 1 4}$ & \multirow{2}{*}{$\begin{array}{c}\text { Changes in } \\
\text { 2014/2003 in \% }\end{array}$} & $\begin{array}{c}\text { Total expenditure in years } \\
\text { 2010-2014 in billion euros }\end{array}$ \\
\cline { 2 - 4 } 1 & Ford Motor & 5.9 & 5.7 & -3.4 & - \\
\hline 2 & Pfizer & 5.7 & 6.8 & 19.3 & 33.5 \\
\hline 3 & DaimlerChrysler & 5.6 & 5.7 & 1.8 & 28.7 \\
\hline 4 & Toyota Motor & 4.9 & 6.9 & 40.8 & 35.9 \\
\hline 5 & General Motors & 4.5 & 6.1 & 35.6 & 30.2 \\
\hline 6 & Volkswagen & 4.1 & 13.1 & 219.5 & 49.8 \\
\hline 7 & Johnson \& Johnson & 3.7 & 7.0 & 89.2 & 31.3 \\
\hline 8 & Microsoft & 3.7 & 9.9 & 167.6 & 42.7 \\
\hline 9 & Intel & 3.5 & 9.5 & 171.4 & 38.0 \\
\hline 10 & Roche & 3.1 & 7.4 & 138.7 & 37.0 \\
\hline 11 & Novartis & 3.0 & 8.2 & 173.3 & 37.4 \\
\hline
\end{tabular}

Source: own study based on Table 2.

The presented analysis of the financial activity of the 20 TNCs with the highest $R \& D$ expenditure indicates that these economic entities have undoubtedly played a key role in $R \& D$ activity in the world, especially in relation to the size of the financial expenditure incurred. That is regardless of the fact that their contribution to global $\mathrm{R} \& \mathrm{D}$ spending over the years covered by the study declined from $10.2 \%$ in 2003 to $8.9 \%$ in 2014 . 


\section{The most innovative transnational corporations in 2015}

Boston Consulting Group, an international strategic consulting company, has been ranking the world's most innovative companies since $2005 .{ }^{3}$ The BCG ranking contains 50 of the most innovative corporations, the biggest number, i.e. 29, comes from the US, 11 from Europe and 10 from Asia. The list also contains emerging markets - these are three companies from China and one from India.

In years 2005-2014, the companies on the innovation lists (Table 5) changed significantly in terms of their affiliation to specific industries. The number of retail corporations decreased from 14 in 2005 to 4 in 2014 and of corporations from sectors such as industry, transport and travel. On the other hand, the number of corporations in the following sectors increased the most: healthcare industry grew from 2 to 8 and finance, automotive and telecommunication.

Table 5 List of the most innovative corporations in 2015

\begin{tabular}{|l|l|l|}
\hline 1. Apple & 18. The Walt Disney Company & 35. Volkswagen \\
\hline 2. Google & 19. Marriott International & 36. Visa \\
\hline 3. Tesla Motors & 20. Johnson \&Johnson & 37. DuPont \\
\hline 4. Microsoft Corp. & 21. Netflix & 38. Hitachi \\
\hline 5. Samsung Group & 22. AXA & 39. Roche \\
\hline 6. Toyota & 23. Hewlett-Packard & 40. 3M \\
\hline 7. BMW & 24. Amgen & 41. NEC \\
\hline 8. Gilead Sciences & 25. Allianz & 42. Medtronic \\
\hline 9. Amazon & 26. Tata Motor & 43. JPMorgan Chase \\
\hline 10. Daimler & 27. General Electrics & 44. Pfizer \\
\hline 11. Bayer & 28. Facebook & 45. Huawei \\
\hline 12. Tencent & 29. BASF & 46. Nike \\
\hline 13. IBM & 30. Siemens & 47. BT Group \\
\hline 14. SoftBank & 31. Cisco Systems & 48. MasterCard \\
\hline 15. Fast Retailing & 32. Dow Chemical Company & 49. Salesfrorce.com \\
\hline 16. Yahoo! & 33. Renault & 50. Lenovo \\
\hline 17. Biogen & 34. Fidelity Investments & - \\
\hline
\end{tabular}

Source: BCG, 2015.

3 The list is developed on the basis of questionnaires conducted by managers representing a wide range of industries in each region of the world. In 2015, to better balance subjective and objective assessments, the answers of respondents for companies operating in their industry were counted at $30 \%$, their own answers for entrepreneurs outside their industry also at 30\%, and (for financial simplification) - a three-year total rate of return was established at $40 \%$. 
Although the criteria for affiliation of TNCs to certain industries were different in the ranking of the companies with the highest $\mathrm{R} \& \mathrm{D}$ spending and the ranking of the most innovative ones, many companies can be found on both lists. This may indicate that the amount of R\&D spending has translated into the results to be considered the most innovative.

Table 6 Number of transnational corporations in each of the 50 most innovative companies in the world in 2005 and 2014

\begin{tabular}{|l|l|c|c|c|c|}
\hline \multirow{2}{*}{ No. } & \multirow{2}{*}{ Industries } & \multicolumn{2}{c|}{2005} & \multicolumn{2}{c|}{2014} \\
\cline { 3 - 6 } & & Number & $\%$ & Number & $\%$ \\
\hline 1 & Automotive & 5 & 10 & 7 & 14 \\
\hline 2 & Retail trade & 14 & 28 & 4 & 8 \\
\hline 3 & Power engineering & 0 & 0 & 0 & 0 \\
\hline 4 & Finances & 2 & 4 & 6 & 12 \\
\hline 5 & Healthcare & 2 & 4 & 8 & 16 \\
\hline 6 & Industry & 7 & 14 & 6 & 12 \\
\hline 7 & Entertainment & 1 & 2 & 1 & 2 \\
\hline 8 & ICT & 16 & 32 & 17 & 34 \\
\hline 9 & Transport and travel & 3 & 6 & 1 & 2 \\
\hline
\end{tabular}

Source: own study based on BCG, 2015.

According to the research conducted among BCG respondents when creating the ranking of the most innovative companies, in 2014 as many as $79 \%$ of the respondents considered innovation to be the most important condition for development while in 2005 only $66 \%$ expressed such an opinion.

BCG's research has shown that corporations that were the first to focus on R\&D gained a significant competitive advantage. These include Apple, Google, Microsoft, Samsung, Toyota, BMW, Amazon, IBM and Hewlett-Packard. In these TNCs, innovations used to be and are very important. These studies show that four attributes that make innovation more effective are becoming increasingly important. They include:

- pressure regarding the speed of action,

- well and effectively implemented R\&D processes,

- use of technology platforms,

- systematic examination of neighbouring markets.

The significance of these attributes is not new, but in recent years they have gained new meaning. For example, the increase of the speed on the market leads to many benefits, both financial and non-financial. Financial benefits are directly 
measurable and far outweigh the costs of introducing "speed" into the market. The examples of the benefits of introducing "speed" include:

- faster innovation - companies focusing on speed in their strategies are able to respond to market needs,

- lower development costs - it releases financial and operational capital, creating resources for other activities that can bring added value to the company,

- a higher market share and more accurate forecasting, as it reduces the time from product design to delivery to the market.

Initiators of most of these ideas and solutions are transnational corporations, which later also reach other companies. It can, therefore, be concluded that TNCs define directions and trends that shape research and development in the world economy.

\section{Conclusions}

When it comes to the expenditure on research and development, transnational corporations alongside countries are among the largest business entities in the world. However, the efficiency of their money is higher than that of countries. The ranking lists evaluating the innovative activity in the $21^{\text {st }}$ century are still dominated by corporations from the Triad even though TNCs from China and India have appeared as well.

The list of the most innovative companies, the number of corporations belonging to particular branches of the economy, has changed significantly. At the moment, it is dominated by TNCs from the IT, healthcare and automotive sectors, while in 2005 it was the ICT, retail and industry sectors. The research has also shown that corporations focusing on R\&D have gained a significant competitive advantage on the market, and they are the ones to form directions and trends shaping this activity on a global scale.

\section{References}

Guinet, J., \& De Backer, K. (2008). The Internationalization of Business R\&D: Evidence, Impacts and Implications. Paris: OECD.

Odrobina, A. (2015). Korporacje transnarodowe jako siła napędowa procesu internacjonalizacji działalności badawczo-rozwojowej. Zeszyty Naukowe Uniwersytetu Szczecińskiego. Studia i Prace Wydziału Nauk Ekonomicznych i Zarządzania, (41/3 Gospodarka regionalna i międzynarodowa), 131-144.

Poznańska, K., \& Kraj, K.M. (2015). Badania i rozwój w korporacjach transnarodowych. Organizacja. Umiędzynarodowienie. Warszawa: Wydawnictwo Naukowe PWN.

Zorska, A. (2007). Korporacje transnarodowe. Przemiany, oddziaływanie, wyzwania. Warszawa: PWE. 


\section{Internet sources}

BCG (2015). The most innovative companies. An interactive guide, retrieved from: https://www. bcgperspectives.com/content/interactive/innovation_growth_most_innovative_companies_interactive_guide [accessed: 02.02.2016].

The 2004 EU industrial R\&D investment scoreboard. Ranking of the top 500 EU companies. (2004). Luxembourg: Publications Office of the European Union, retrieved from: http:// iri.jrc.ec.europa.eu/scoreboard04.html [accessed: 22.03.2016].

The 2004 EU industrial ReD investment scoreboard. Ranking of the top 500 non-EU companies. (2004). Luxembourg: Publications Office of the European Union, retrieved from: http://iri. jrc.ec.europa.eu/scoreboard04.html [accessed: 22.03.2016].

The 2008 EU industrial R\&D investment scoreboard. R\&D ranking of the top 1000 EU companies. (2008). Luxembourg: Publications Office of the European Union, retrieved from: http://iri.jrc.ec.europa.eu/scoreboard08.html [accessed: 22.03.2016].

The 2008 EU industrial R\&D investment scoreboard. R\&D ranking of the top 1000 non-EU companies. (2008). Luxembourg: Publications Office of the European Union, retrieved from: http://iri.jrc.ec.europa.eu/scoreboard08.html [accessed: 22.03.2016].

The 2014 Ranking World top 2500 companies. (2014). Luxembourg: Publications Office of the European Union, retrieved from: http://iri.jrc.ec.europa.eu/scoreboard14.html [accessed: 22.03.2016].

The 2015 EU industrial R\&D investment scoreboard. R\&D ranking of the top 1000 non-EU companies. (2015). Luxembourg: Publications Office of the European Union, retrieved from: http://iri.jrc.ec.europa.eu/scoreboard.html [accessed: 22.03.2016].

\section{Note about the Author}

Piotr Chechelski - Professor at the Institute of Agricultural and Food Economics - National Research Institute. He is the author of about 300 scientific publications. He deals with issues related to the economics of food industry companies as well as transnational corporations. 